\title{
Software product management: planning tool integration
}

\author{
Andrey Polianskii ${ }^{1}$, Darya Chukalova $^{2}$ \\ ${ }^{1}$ Docent, candidate of technical sciences, Vologda State University, Vologda; \\ ${ }^{2}$ Postgraduate, Vologda State University, Vologda.
}

\begin{abstract}
The article discusses the problems of using software for project management and calculating the complexity of design work on the example of planning projects for the production of software products. Approaches to using project management standards and the project subject area to form a work breakdown structure, calculating the complexity of individual work packages and the project as a whole are investigated, requirements for integration software are formulated.

Keywords: work breakdown structure, labor calculator, project management, product life cycle processes.
\end{abstract}

\section{Introduction}

Management of the production of software products is built, as a rule, on a project basis. A sufficient number of various software tools are available on the market that allows you to plan and manage projects, however, in their practical application, often the bottleneck becomes the definition of the work breakdown structure (hereinafter - WBS), the calculation and evidence of the objectivity of the estimates of the complexity of certain types of work and the project generally. The development and implementation of solutions for the integration of project management systems with systems that can objectively determine the types, labor intensity and cost of project work seem to be a very urgent task.

\section{Methods and materials}

The purpose of the research is based on the analysis of recommendations of standards, the capabilities of software products for project management and means of calculating the complexity of project work, propose a method for their joint use and formulate requirements for a system solution for their integration.

Research objectives:

— to study the requirements of software engineering standards and project management techniques for the content of design work, methods of planning and accounting for labor costs;

— to analyze the capabilities of popular software products for project management and means of calculating the complexity of work, the possibilities of their integration; 
— to propose a methodology for the joint use of project management tools (hereinafter referred to as PMT) and means for calculating the complexity of project work (hereinafter referred to as CCPW) for project planning;

- to develop requirements for integration software that allows you to form WBS in a form convenient for the project manager, set parameters and obtain the results of labor-intensive calculations of certain types of work.

Object of research: standards, methods, and software products of project management and calculation of the complexity of project work in software engineering.

Subject of research: a methodology for constructing WBS and determining their complexity, requirements for a system solution for the integration of software products for project management and calculation of the complexity of project work.

Among the standards of software engineering that determine the content of design work, first of all, attention should be paid to ISO/IEC/IEEE 12207: 2017 [1]. In the 2017 edition, the standard is harmonized in the number of product life cycle processes (30) with ISO/IEC/IEEE 15288-2015. From the description of the product life cycle processes, the project manager can select useful information for constructing the WBS and the system of intermediate events and project results (activity and process outputs). Unfortunately, in the practice of customer relations, it is necessary to use versions of the standards of the previous generation $[2,3]$, which differ in the structure of processes and terminology.

In software projects, the work is usually structured according to the main phases of development: definition of requirements, architectural and detailed design, code writing and debugging, testing, implementation. The Rational Unified Process methodology (hereinafter referred to as RUP) [4], offers 4 phases: Inception (initiation), Elaboration (design), Construction (construction), Transition (transfer to the customer, implementation) and describes the processes in terms of "workers", "activity", "artifacts", "workflows". If the product is complex, it can be divided into increments - relatively independent modules developed and implemented separately from each other in their cycles.

For example, GOST R ISO/IEC 12207-2010 describes a risk management process that is performed to identify, process and analyze risks. Table 1 presents the process objectives selected from the text of the standard and an example of an expert assessment of their duration for subsequent calculation.

Table 1. Objectives of the risk management process and expert assessment of their duration

\begin{tabular}{|c|l|c|c|c|}
\hline No. & \multicolumn{1}{|c|}{ Task name } & $\begin{array}{c}\text { Optimistic } \\
\text { value (days) }\end{array}$ & $\begin{array}{c}\text { Best possible } \\
\text { value (days) }\end{array}$ & $\begin{array}{c}\text { Pessimistic } \\
\text { value (days) }\end{array}$ \\
\hline 1 & Determining the scope of the process & 7 & 10 & 12 \\
\hline 2 & $\begin{array}{l}\text { Defining and implementing a process } \\
\text { strategy }\end{array}$ & 4 & 5 & 6 \\
\hline 3 & $\begin{array}{l}\text { Identification of risks as they are } \\
\text { identified during the project, Including } \\
\text { their identification, probability of } \\
\text { occurrence and consequences }\end{array}$ & 4 & 7 & 9 \\
\hline 4 & $\begin{array}{l}\text { Risk analysis and prioritization application and } \\
\text { assessment of risk to identify changes in } \\
\text { risk status }\end{array}$ & 3 & 4 & 5 \\
\hline 6 & $\begin{array}{l}\text { Risk treatment to correct/avoid } \\
\text { exposure }\end{array}$ & 4 & 7 & 9 \\
\hline
\end{tabular}

There are many standards and methodologies for project management that can become a source of complement to WBS in terms of organizational, managerial and control work (personnel management, configuration, quality, etc.). First of all, we note GOST R ISO 
21500-2014 [5], which contains descriptions of the main project management processes to the level of individual tasks. The section "Estimating the duration of work" is devoted to the problem of calculating the complexity of a project. The standard defines a set of factors on which the duration of work depends: the number and type of available resources, the relationship between jobs, productivity, etc. Most often, the duration of the work is a compromise between resource availability and time limits.

The next source useful for assessing the duration of project management is the International Competence Baseline, proposed by the International Project Management Association (ICB IPMA) [6]. This is a document defining a system of requirements for the level of competence of project managers. ICB IPMA defines the areas of qualifications and competencies in project management, as well as the principles for assessing the capabilities of a candidate for the role of a project manager. Three groups of competency elements are considered: technical competency, behavioral competency, contextual competence. In WBS project, the quality and duration of management work depend on the level of competence of managers.

GOST R ISO 10006 - 2019 [7] is dedicated to the rational and effective quality control of project processes. It is assumed that all calculations related to the assessment of the complexity of processes, human, material, time resources are carried out at the stage of project initiation, during the development of a project management plan. It is recommended to periodically evaluate the progress of the project in order to take into account completed work and planning the remaining work, and monitoring the status of the project as a whole. Quality management work should be included in WBS and evaluated in terms of their resource intensity.

Using the above sources, an integrated WBS that does not contradict the standards is obtained. The further breakdown into work packages will depend on the structure of the project team, the level of qualification and the degree of independence of the performers, technologies and development environments.

The next objective of the research is the analysis of methods for assessing the complexity of work.

The most common assessment option is PERT method [8], which, based on expert estimates of an optimistic, pessimistic, and most likely forecast from the expert's point of view (for example, Table 1), allows one to derive an average estimate of the laboriousness of works of different complexity and duration. The main problem of the methodology is the quality of expertise and the ability to prove its objectivity to the customer and project sponsors.

There are methods and norms for determining the complexity of work, taking as a basis volumetric (for example, COCOMO) [9] or structural and functional (for example, IFPUG, CETIN) [10,11] characteristics of the future product. The methods [10, 11] contain algorithms for determining the functional size of a product, calculating the complexity and cost of its development and maintenance. They also take into account the quality and technical requirements, the experience of the development team and organization, development tools, etc. If the use of methods based on volume indicators gives, as a rule, only a general assessment of the complexity of the project as a whole, then structural and functional methods allow us to estimate the complexity of the development of components, and CETIN, in addition, divide the calculations into 6 main RUP processes and establish relative characteristics of the significance of individual stages of work in the total complexity.

In the course of analyzing the functionality of popular software products for project management, the well-known PMTs were investigated: Trello, Asana, Megaplan, Open Project, Basecamp, MC Project.

General requirements for PMT:

— ability to aggregate information for user-defined structures; 
— the ability to set the scope of work for the subsequent determination of their duration;

— use of resource calendars and work calendars;

— scheduling according to resource constraints.

Additionally, an analysis was performed for the presence of built-in functions for calculating the labor intensity of individual works, the presence of an open application interface (API) or extension development tools (SDK). Comparative advantages and disadvantages of such products are presented in table 2 .

Table 2. Comparative advantages and disadvantages of PMT

\begin{tabular}{|c|c|c|}
\hline Name & Advantages & Disadvantages \\
\hline Trello & $\begin{array}{l}\text { - intuitive interface; } \\
\text { - it is possible to appoint responsible } \\
\text { for a specific job; } \\
\text { - Web-clipper allows you to create a } \\
\text { card in Trello, pulling into it the name } \\
\text { of the web page, link and illustration } \\
\text { of the current site; } \\
\text { - third-party services and add-ons can } \\
\text { be connected to Trello through the } \\
\text { API; } \\
\text { - no limit on the number of users. }\end{array}$ & $\begin{array}{l}\text { - there is no Gantt chart that is useful } \\
\text { in project management; } \\
\text { - it is impossible to evaluate progress } \\
\text { over time; } \\
\text { - in the free version you can connect } \\
\text { only one service to each board, } \\
\text { different to different boards; } \\
\text { - there is no labor calculator; } \\
\text { - inconvenient for large projects. }\end{array}$ \\
\hline Asana & $\begin{array}{l}\text { - the ability to divide a complex } \\
\text { project into areas of activity; } \\
\text { - a high degree of detail of projects is } \\
\text { available; } \\
\text { - intuitive interface; } \\
\text { - integration with Dropbox, Google } \\
\text { Drive, Evernote, etc. }\end{array}$ & $\begin{array}{l}\text { - there is no Russian version; } \\
\text { - there is no labor calculator; } \\
\text { - missing Gantt chart. }\end{array}$ \\
\hline Megaplan & $\begin{array}{l}\text { - the ability to integrate with } 1 \mathrm{C} \text { and } \\
\text { communication networks; } \\
\text { - Gantt chart to represent the timeline, } \\
\text { fixing the project milestones; } \\
\text { - A convenient messenger for } \\
\text { employees and customers. }\end{array}$ & $\begin{array}{l}\text { - difficult initial setup; } \\
\text { - there is no labor calculator; - } \\
\text { redundancy of functions for small } \\
\text { projects. }\end{array}$ \\
\hline Open Project & $\begin{array}{l}\text { - ease of development; } \\
\text { - simplicity of the interface; } \\
\text { - open API. }\end{array}$ & - there is no labor calculator. \\
\hline Basecamp & $\begin{array}{l}\text { - simple and intuitive interface; } \\
\text { - automatic check for the availability } \\
\text { of employees; } \\
\text { - reports on projects in the form of } \\
\text { informative schedules. }\end{array}$ & $\begin{array}{l}\text { - there is no Russian version; } \\
\text { - there is no labor calculator; } \\
\text { - no strategic planning tools. }\end{array}$ \\
\hline MS Prodect & $\begin{array}{l}\text { - relatively short training time for } \\
\text { users familiar with Microsoft Office }\end{array}$ & $\begin{array}{l}\text { - there is no labor calculator; } \\
\text { - insufficient reliability of the server } \\
\text { side. }\end{array}$ \\
\hline
\end{tabular}

A common drawback of the considered products from the point of view of project labor intensity planning is the lack of built-in tools for determining the labor intensity of works, with the exception of the expert assessment of the project manager, which is performed outside the system, and the result is written in the form of a deterministic value in the corresponding property of the work. A number of products allow the extension of a set of properties when describing works; accordingly, probabilistic estimates can be used.

PMT developers do not include labor-intensive calculators in them, so as not to limit the versatility of the product since, for different industries and types of work, there are different 
methods for assessing the laboriousness of work. However, it is often important not only in relation to the customer but also with the project team to quickly determine the overall complexity of the project and the complexity of individual works based on industryrecognized methods and standards.

In software engineering, various labor-intensive labor calculators are known, which mainly implement various versions of the COCOMO methodology, for example, $[12,13]$. The product interfaces allow you to manually enter the set of parameters necessary for the calculation (from 10 to 20 or more), determining the volume of the solution in thousands of lines of code or at functional points, some allow you to use the similarity of PERT method. The result of the calculation in a given time scale (usually man-months) is displayed on the screen; you can also get a monetary value if you set the cost of the labor unions. A text file is generated with detailed calculation results and even a schedule of load distribution by months of the project.

There are various ways of integrating the types of software products discussed above, which mainly depend on the model of their distribution and openness of the program code. In the most difficult case, for proprietary products, integration is possible only at the level of information presentation formats. For project management tools, it is necessary to provide the input of the labor-intensiveness characteristics in a given unit of measurement, and for the labor-intensive calculators, it is necessary to enter the characteristics of the project team, development tools, features of the product requirements, etc. according to the accepted model of calculations. If the products allow data input and output in the form of files of various formats, the integration task is solved using a converter.

\section{Results}

The methodology for the joint use of PMT and CCPW tools for planning the complexity of a project proposed by the authors includes:

- determination of project management standards and product (software) life cycle processes and their coordination with sponsors and the project customer;

- selection and construction of a sequence of project processes based on recommendations of standards in WBS (enlarged on the Gantt chart);

- allocation of project phases and distribution of processes into phases with a breakdown into enlarged work packages;

- calculation in CCPW according to the method agreed upon with the customer of the characteristics of the laboriousness of enlarged work packages (for CETIN method) or the project as a whole for versions of COCOMO method;

- the breakdown of enlarged work packages into parts to which a specific contractor can be assigned, with a refinement of the labor intensity assessment within the framework of the total labor intensity of the enlarged package (project).

The most promising option is the development of the original CCPW, which allows a quantitative assessment of the complexity of certain types of work at different phases of the project (CETIN methodology), and a tool for constructing WBS model based on the ISO 12207-2017 process system.

We define the following basic requirements for software for integration of PMT and CCPW:

- the ability to transfer the source data with the general characteristics of the project from PMT to CCPW and the results of calculations in the opposite direction with minimal human participation, mainly through the data buffer of the operating system; 
- an intuitive interface, the main solutions of which are similar to the solutions for PMT or CCPW;

- use of standard formats and data types when transferring information between system components;

— the ability to export source data and calculation results to MS Excel;

- the ability to prepare WBS template file based on the texts of regulatory documents (using Open Office tools);

— the ability to perform operations to adjust the regulatory framework of CCPW, if it allows updating of the databases.

In conclusion, we note that as a result of the study:

- identified requirements of standards for the content of design work, methods of planning and accounting for labor costs in the project;

- analyzed the functionality of popular PMT and CCPW, the possibilities of their integration;

- a methodology for the joint use of PMT and CCPW for the planning of the project's labor input is proposed;

- the requirements for integration software are defined that allow forming the project WBS in a convenient form for the project manager, set parameters and obtain the results of labor-intensive calculations of certain types of work.

\section{Conclusion}

A similar approach can be used for planning projects in other industries, where there are regulatory documents that determine the processes of creating a product and methods for calculating the labor input of the main types of work, in particular, in construction or in mechanical engineering.

\section{References}

1. ISO/IEC/IEEE 12207:2017. Systems and software engineering — Software life cycle processes [Electronic source]: official site. - access mode: https://www.iso.org/ru/standard/63712.html.

2. GOST R ISO/IEC 12207-2010. Information technology. System life cycle processes. - intr. 03/01/2011. - Moscow: Standartinform, 2011. - 104 p.

3. GOST R ISO/IEC 15288-2005. Information technology. System engineering. System life cycle processes. - intr. 01/01/2007. - Moscow: IPC Publishing House of Standards, 2006. $-58 \mathrm{p}$.

4. Rational Unified Process. Best Practices for Software Development Teams [Electronic source]: official site. https://www.ibm.com/developerworks/rational/library/content/03July/1000/1251/1 251 bestpractices TP026B.pdf

5. GOST R ISO 21500-2014. Project management guide. - intr. 03/01/2015. - Mosow: Standartinform, 2015. $-52 \mathrm{p}$.

6. IPMA requirements for the competence of professionals in the management of projects, programs and portfolios, 4th version. [Electronic resource]: official site. -access mode: http://www.sovnet.ru/docs/news

7. GOST R ISO 10006-2019 Quality management. Guidelines for quality management in projects. - intr. 10/01/2020. - Moscow: Standartinform, 2019. - 32 p. 
8. PERT Guide For Project Managers and Productivity Gurus [Electronic resource]: official site. - Access mode: https://www.ntaskmanager.com/blog/pert-guide-for-projectmanagers-and-productivity-gurus/

9. Software Engineering. COCOMO Model [Electronic resource]: official site. - Access mode: https://www.geeksforgeeks.org/software-engineering-cocomo-model/

10. International Function Point Users Group [Electronic resource]: official site. - Access mode: https://www.ifpug.org/the-international-function-point-users-groupannounces-the-release-of-version-4-3-of-the-counting-practices-manual/?lang=ru

11. ST RK ISO/IEC 20968-2009. Software engineering. Point functional assessment. Guide to practical calculations. - intr. 11/17/2009. - Astana: RSE Kazakhstan Institute of Standartization and Sertification, 2009. - 180 p.

12. Labor calculation COCOMO Suite of Constructive Cost Models [Electronic resource]: official site. - Access mode: https://csse.usc.edu/tools/COCOMOSuite.php.

13. COCOMO ${ }^{\circledR}$ II with Heuristic Risk Assessment [Electronic resource]: official site. Access

mode: http://sunset.usc.edu/research/COCOMOII/expert_cocomo/expert_cocomo2000.ht $\mathrm{ml}$. 